Article

\title{
Private Forest Governance, Public Policy Impacts: The Forest Stewardship Council in Russia and Brazil
}

\author{
Lisa McIntosh Sundstrom ${ }^{1, *}$ (1) and Laura A. Henry ${ }^{2}$ \\ 1 Department of Political Science, University of British Columbia, Vancouver, BC V6T 1Z4, Canada \\ 2 Department of Government and Legal Studies, Bowdoin College, Brunswick, ME 04011, USA; \\ lhenry@bowdoin.edu \\ * Correspondence: lisa.sundstrom@ubc.ca; Tel.: +1-604-822-6331
}

Received: 29 August 2017; Accepted: 10 November 2017; Published: 16 November 2017

\begin{abstract}
Under what conditions do private forest governance standards influence state policy and behavior to become more oriented toward sustainability? We argue that governance schemes targeting firms may indirectly shape state behavior, even when designed to bypass state regulation. Through an examination of the Forest Stewardship Council (FSC) in Russia and Brazil, we find that the FSC has influenced domestic rhetoric, laws, and enforcement practices. FSC has had a more disruptive and consequential impact on Russia's domestic forest governance; in Brazil, earlier transnational environmental campaigns had already begun to shift domestic institutions toward sustainability. Based on interview data and textual analysis of FSC and government documents, we identify the mechanisms of indirect FSC influence on states-professionalization, civil society mobilization, firm lobbying, and international market pressure, and argue that they are likely to be activated under conditions of poor and decentralized governance, overlapping and competing regulations and high foreign market demand for exports.
\end{abstract}

Keywords: forests; certification; private governance; Russia; Brazil

\section{Introduction}

When do market-based campaigns for more sustainably produced consumer goods lead to changes in how states regulate? Could an NGO-driven private forest certification body directed toward industry indirectly influence states' forest governance as well? In this article, we argue that in some cases, private governance shapes state behavior, even when the original architects designed the governance scheme to work around states or to fill gaps in state regulation [1] (p. 97). While private certification labels exist for a wide range of products, from food to textiles to construction material, the best-known global certification body is the Forest Stewardship Council (FSC). Nonstate actors created the FSC in the 1990s as a multi-stakeholder global governance initiative to develop standards for certifying the ecological and social sustainability of forest products and raise global consumer awareness and market demand for certified products. Forest industry actors' compliance with these standards ideally is driven by market competition; companies wish to gain market access and increase exports, and without FSC certification and labeling, their prospects for expansion may be constrained. The FSC has become a mechanism through which industry actors learn new forest management practices and a tool in the hands of domestic NGOs, providing a means to monitor forest companies. However, in addition to the direct effects that FSC has in changing the practices of private actors, and despite some scholarship on the role of the state creating the context for certification, there are underexplored indirect effects of private certification on state forest regulation, particularly in countries with poor state forest governance outside the Global North.

We compare the domestic policy impacts of FSC in two key countries with different political regime types where FSC certification is widespread, yet sustainable forest governance has remained 
problematic. First, Russia, a major forest producer, has a poor record of forest sustainability, an authoritarian governing regime, and a weak civil society. Brazil, our secondary case, also is a major forest producer that has improved its forest governance institutions significantly in recent decades. Brazil boasts a reasonably healthy democratic regime and influential environmental groups supported by global concern for the widely publicized destruction of Amazonian forests. However, Brazil's forest governance is still hampered by weak state institutions and high levels of corruption. In both states, the number of FSC certificates held by private industry has expanded significantly in the recent past. Yet given levels of corruption and weak, opaque state forest governance institutions, we expect these two countries to be difficult tests for the capacity of FSC principles to affect state policy.

Our analysis paradoxically suggests that the impact of FSC standards on state policy may be greater in countries with weaker governance institutions and environmental movements than in countries where these institutions and actors are stronger. Given the countries' different degrees of democracy and different strengths and longevity of environmental movements, we might expect that the impact of FSC would be stronger in Brazil than in Russia. However, we argue that the impact of the FSC is in part dependent on the regulatory gap between private and state standards and the timing of FSC intervention. Specifically, we first find that Russia and Brazil share many of the facilitating conditions that ultimately allow the FSC to influence state policy-poor and decentralized governance, overlapping regulatory standards, and high foreign market demand for forest products. We suggest that other states with similar conditions also may be subject to the indirect influence of private governance on state regulation. Second, we find that the FSC's impacts in Russia have been puzzlingly stronger than in Brazil, albeit region-dependent. In Russia, the initial gap between domestic forest governance and FSC principles and criteria was greater than that in Brazil. Moreover, while there was already a strong domestic and transnational environmental movement at work on deforestation in the Amazon when FSC was introduced, for Russian NGO activists the FSC was the first global mechanism that empowered NGOs to challenge traditional forest management. For that reason, in Russia, the introduction of FSC has been more conflictual than in Brazil and, counterintuitively, has led to greater influence on state policies and practices, especially in regions where market incentives support certification. This is an important finding, suggesting that private certification not only fills regulatory gaps, but under certain conditions may change the evolution of state regulation over time.

\section{Reviewing the Literature: Private Governance Influence on States}

An extensive literature on FSC as a private, market-driven governance institution focuses on why forest companies decide to pursue certification [2,3], rates of certification in different jurisdictions [4-6], [7] (p. 82), impacts of certification on participating companies [8,9], and NGOs' roles in promoting the FSC to industry and consumers $[1,10,11]$. Scholars are interested in the FSC as a mechanism because it is an example of a new form of global governance that rests in the hands of private, nonstate actors. Traditional understandings of "governance," or "the maintenance of collective order, the achievement of collective goals, and the collective processes of rule through which order and goals are sought" [12] (p. 175), have understood it to fall within the purview of governments. Yet private certification initiatives like FSC generally are intended to go beyond or around government regulation, creating new models of global governance. This direct appeal to private actors has been the primary focus of existing scholarship [13,14]. As a result, the state itself has not featured prominently in studies of FSC or private certification broadly, although there are exceptions [7,15-17]. Existing work that notes the role of the state tends to focus on private environmental governance as a replacement for state-based governance $[18,19]$; how states, primarily the Northern industrialized democracies, shape private certification initiatives [7]; and how FSC acts as a co-regulator in states with strong institutions [17]. A separate line of inquiry highlights on-going contestation over rule-making authority between state and private actors. Once private governance gains adherents, certain bureaucracies within the state will attempt to reclaim authority over forest 
governance through state-driven certification schemes [20,21], a clear state response that is unlikely to occur in the absence of private certification.

Yet to truly understand how private governance may influence state-based government by changing the rhetoric, policies, and practices of state actors charged with governing the forest sector, we need to analyze the conditions under which private certification standards shape state regulation, particularly in countries with poor governance records. Based on a thorough review of the literature, we hypothesize that certification initiatives targeted at private actors, such as FSC, are more likely to influence state actors under the following conditions:

- When the outcomes of state regulation are poor-economically, environmentally, or socially;

- When governance of the industry is decentralized, and a large number of actors and agencies come into contact with private standards;

- When overlapping rules and standards create areas of competition and/or conflict between state law and private governance; and

- When foreign markets demand certified products.

How do these conditions matter? First, poor state governance creates a "problem" that is widely recognized by state and nonstate actors [22] (pp. 106-107). Acknowledgment that existing policies or institutions are ineffective sets the stage for outside influence [23] (pp. 17-20). "Critical junctures" occur when old policies or institutions are perceived as failing or when there is an identified gap in regulation, leading policy makers to be more open to borrowing solutions from elsewhere [23] (pp. 17-20), [24]. Second, decentralized state authority creates multiple decision making venues where the alternative governance schemes may have an effect [25] (p. 172), [26]. Lemos and Agrawal suggest that when environmental governance is decentralized, "dissatisfaction with governance can find local points of authority against which to protest" [26] (p. 34). The fragmentation of authority often leads to greater access for companies and civil society groups [16] (p. 601). Third, global standards that directly overlap with state regulation create a competitive dynamic between the two governance systems which can prompt convergence [7] (p. 85), [17] (p. 2), [27]. Overdevest and Zeitlin examine the interaction of transnational regimes in the forest sector and find that "the competition between private schemes resulted in mutual adjustment and upward convergence of standards, without completely closing the gap between them" [27] (p. 42), [17] (p. 2). We argue that this competitive dynamic creates opportunities for change in state regulation as well. Finally, foreign buyers of exported goods can facilitate compliance with global standards, including environmental standards, whether due to external jurisdictions' regulatory requirements, supply-chain concerns of multinational corporations (MNCs) to whom domestic firms are selling products, or consumer demand [28,29]. The role of export markets has been observed specifically in the case of FSC [16] (p. 593), [30] (p. 59), [7], [31] (pp. 587-588).

These facilitating conditions matter because they trigger mechanisms that encourage state and nonstate actors to favor private environmental or social standards. These mechanisms include state officials' desire for professionalization and revenue maximization, lobbying by domestic firms, and pressure from civil society mobilization. Yet the strength of these mechanisms can vary. In the following sections, we explore the facilitating conditions for FSC influence on the state in Russia and Brazil.

\section{Materials and Methods}

Our analysis is qualitative, involving structured comparisons across two cases, with Russia as our primary case and Brazil as a key comparative referent. This most different systems design, given that Russia and Brazil vary on a broad array of measures (regime type, state-society relations), yet both governments face a rival governance model in the forest sector, allows us to identify similar causal patterns across the two cases. We also delve into subnational variations where helpful for additional leverage. We thus combine a comparative case design logic with a within-case logic by comparing factors not only cross-nationally, but also across regions within each country that exhibit variations in external market demand and forest governance quality. 
Data are drawn from field research interviews conducted in person by the authors in Moscow, Russia in the summer of 2014 and two interviews with FSC-Brazil participants conducted via Skype in 2016 (see Appendix A). In addition, we examined state forestry legislation, including parliamentary legislation, executive orders, and material from the Russian and Brazilian forest agencies (Rosleskhoz and Serviço Florestal Brasileiro)—including the revisions to Russia's Forest Code and the creation and revision of Brazil's Public Forest Management Law - from the period prior to the introduction of FSC certification to the present. This analysis incorporated text searches for the appearance of key terms potentially linked to FSC, including "forest certification", "biodiversity", "sustainable", and "indigenous". We also examined FSC documents regarding changing standards and compliance in both countries. Collectively, these documents allowed us to trace the timing and process of changing government policy and practice following the introduction of FSC. The comparisons provide an opportunity to evaluate which background conditions trigger mechanisms that facilitate FSC influence on state policy in both states. We consider and reject the counterfactual possibility that the same policy outcomes would have occurred in the absence of FSC in Russia or Brazil.

\section{Background: The FSC in Russia and Brazil}

There is no global forestry regime [19]. Instead, overlapping forest governance initiatives have emerged in a system of "complex global governance" [16] (pp. 594-595). The most successful of these is the Forest Stewardship Council's certification program. The FSC was founded in 1993 to "promote environmentally appropriate, socially beneficial, and economically viable management of the world's forests" [32]. The FSC develops principles and criteria for sustainable forest management that are translated into national-level standards and indicators. Principles range from compliance with domestic laws, to maintaining forest biodiversity, including "high conservation value forests" (HCVFs), and recognizing indigenous, community, and workers' rights [33]. Companies may apply for forest management and chain of custody certification; once certified, they can use the FSC label to market their products to environmentally sensitive consumers. Ultimately, the attractiveness of FSC certification depends on the demand for certified products.

Russia and Brazil are the two states with the greatest proportion of world forests, with Russia containing 20\% and Brazil 13\% [34,35]. Both countries have a federalized system of governance, with the federal and regional levels both retaining some authority for forest regulation [35]. In Brazil, there are different rules governing native forests, plantation, and indigenous or community forestry. In Russia, there has been significant instability in the forest code after the sector experienced a crisis of illegality in the 1990s. For both countries, the timber industry is an important economic sector, although its significance is greater in Brazil. By 2003, the forestry sector accounted for about 6.9 percent of total GDP in Brazil [36]. In 2012, the forestry sector constituted only 1.3 percent of Russia's total GDP [37]. Brazil is the world's second largest producer of tropical wood, primarily from the Amazon [35] (p. 227), while Russia exports more unprocessed roundwood than any other country [38] (pp. 267-268).

The FSC began operating in Brazil in 1994 and the FSC Brazil office was formally established in 2001 [39] (pp. 35-36); it closed in 2008 due to financial difficulties before reopening in 2010 (Werneburg 2016). The FSC became active in Russia in 1997 and opened an office in Moscow in 2005 [40] (p. 274). FSC certification has advanced significantly in both states (Figures 1-3). As of 2015, 6.29 million hectares of Brazilian forests were FSC certified, including 102 forest management certificates and 1074 chain of custody certificates, comprising 1 percent of total forested area. At the same time, nearly 39 million hectares of Russian forests were certified, accounting for more than 20 percent of all forests under lease for timber production and 5 percent of total forested area [41-43]. As of 2015, FSC had approved 118 forest management certificates and 324 chain of custody certificates in Russia. 


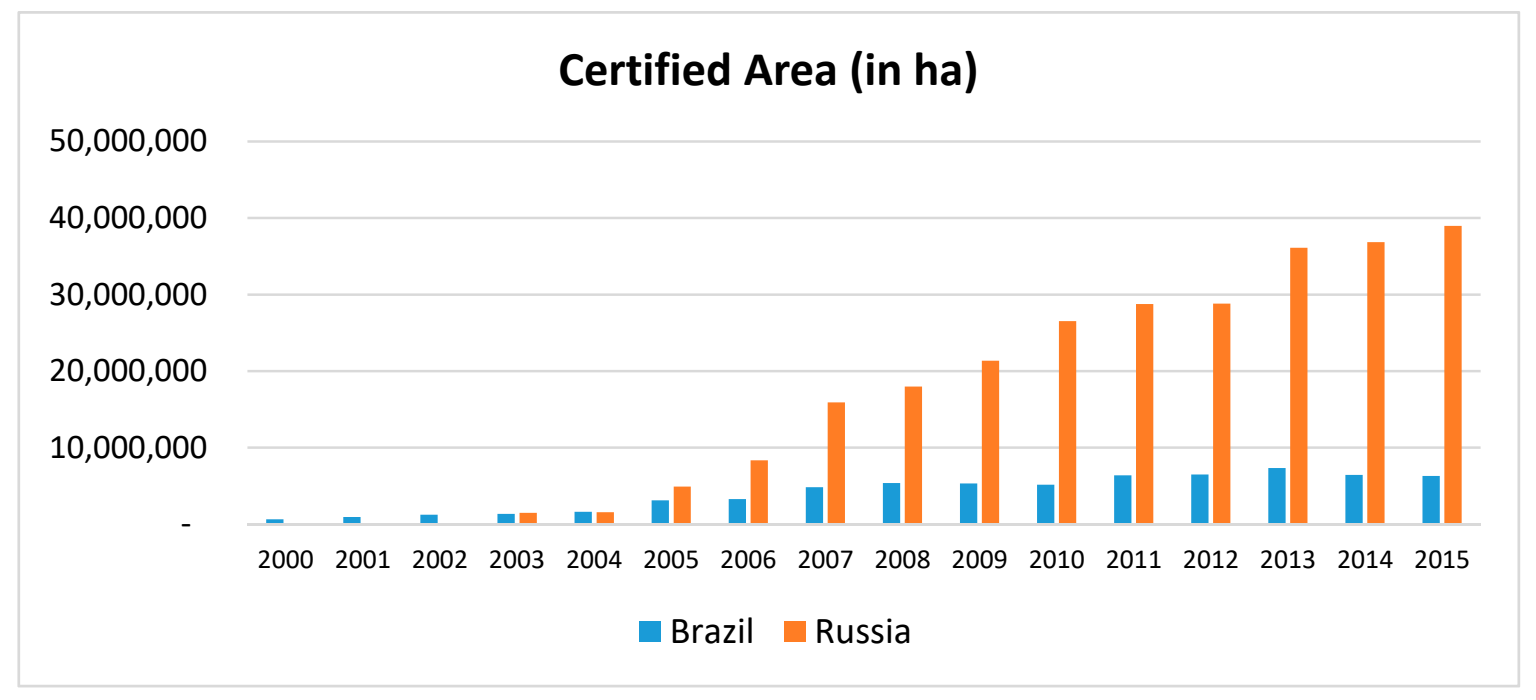

Figure 1. Total area (in hectares) of Forest Stewardship Council (FSC)-certified forest territory in Brazil and Russia, 2000-2015. Source: FSC International.

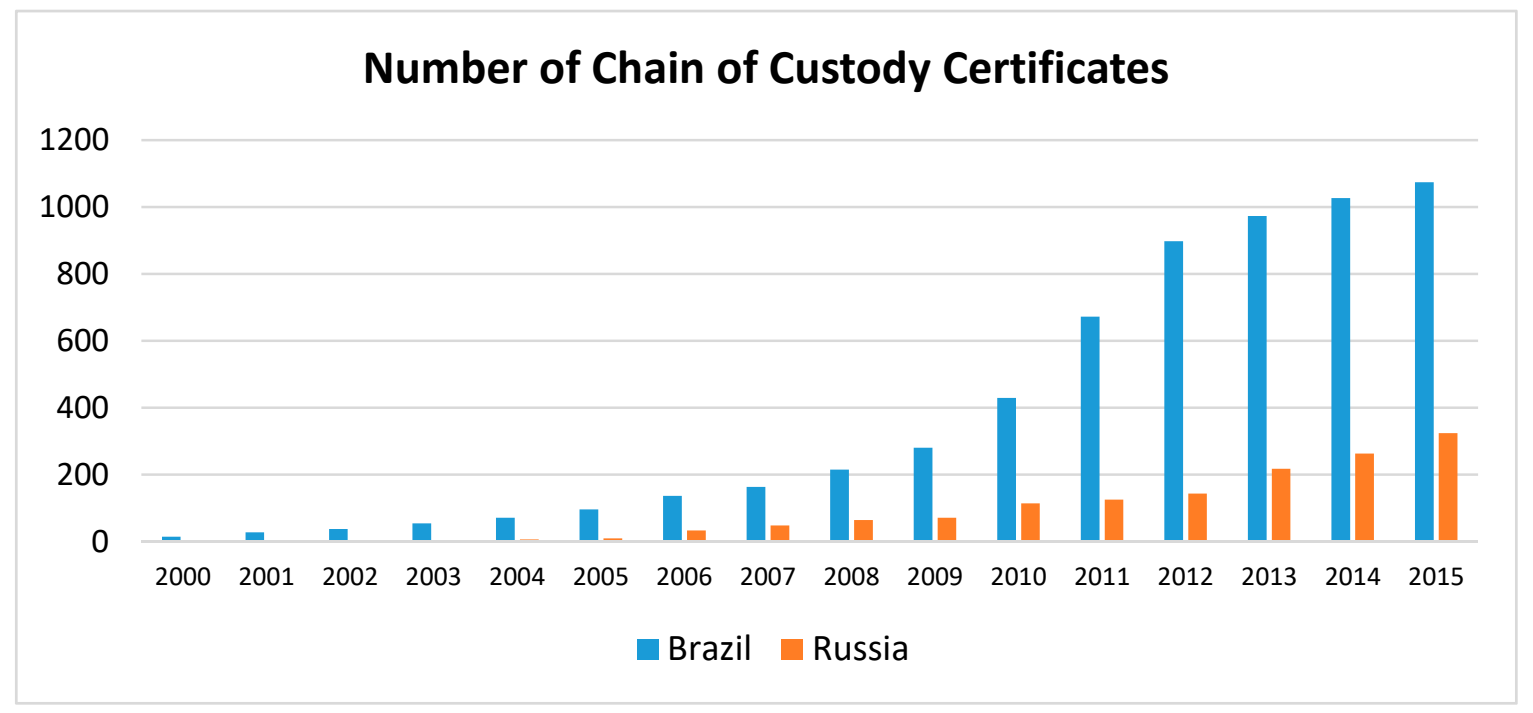

Figure 2. Number of FSC chain of custody certificates granted in Brazil and Russia, 2000-2015. Source: FSC International.

The rapid growth in the area certified under FSC and the number of certificates creates similar pressure on state-based regulation in Russia and Brazil-albeit with a greater percentage of forested territory certified in Russia and greater relative economic impact in Brazil. The facilitating conditions and mechanisms of FSC influence are shared in both countries, but to varying degrees. Below, we discuss the conditions and mechanisms driving FSC influence in the Russian case, followed by a brief comparison with the Brazilian case. 


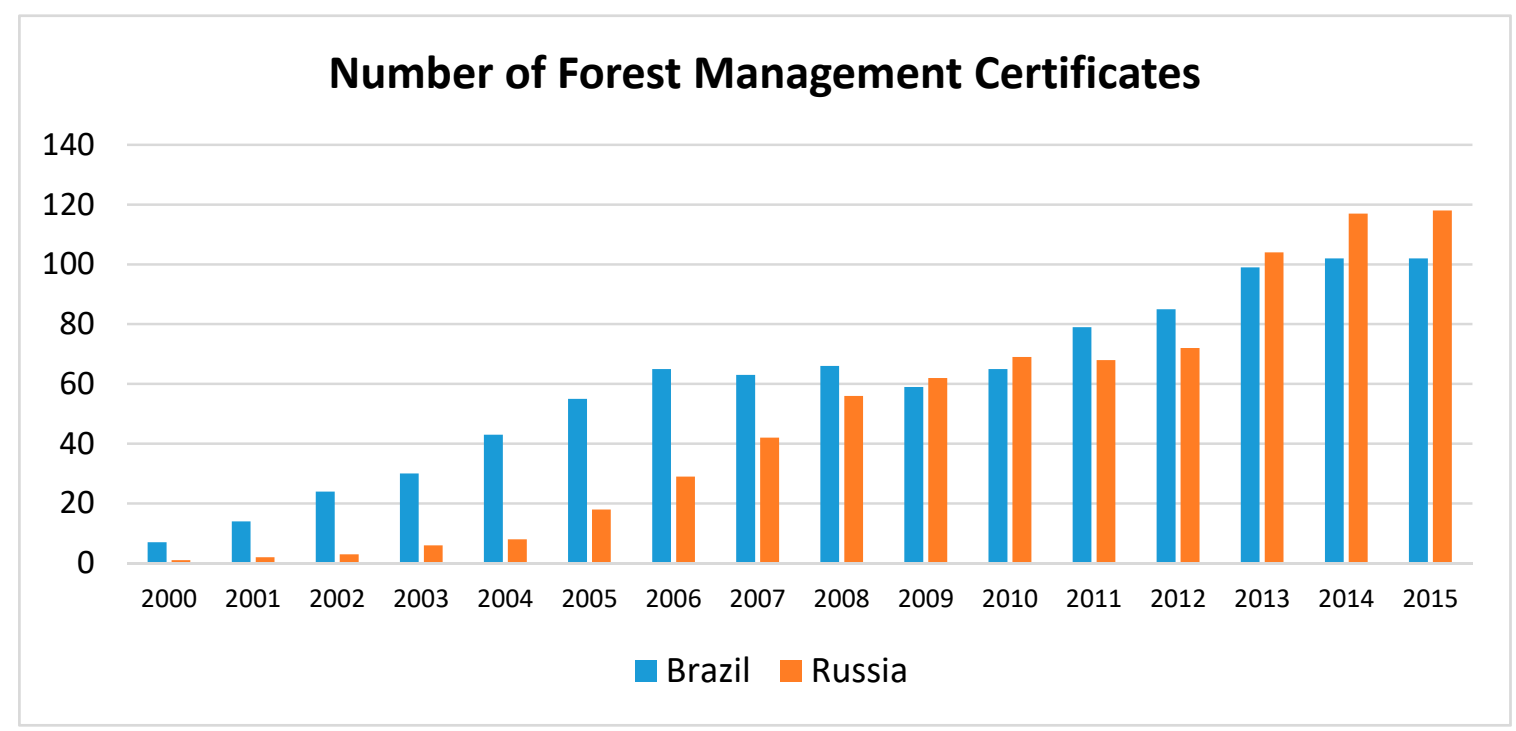

Figure 3. Number of FSC forest management certificates granted in Brazil and Russia, 2000-2015.

Source: FSC International.

\section{FSC Certification Influence on the Russian State}

Russian forest industry actors' decision to pursue certification places companies under the authority of two overlapping governance regimes-state-based regulation and private certification standards. Private certification also creates challenges and opportunities for state officials who must decide whether to embrace, reject, or ignore the alternative governance model. We find that the indirect influence of FSC certification on Russian state forest governance is apparent in new or revised policies, including the language of sustainable forestry and competing domestic certification schemes, and new enforcement practices to accommodate certification.

\subsection{Revisions to State Policy}

Russia's state forestry institutions have been characterized by a high degree of instability, with major changes to the federal Forest Code in 1993, 1997, and 2006, and reforms again under consideration. The Russian Forestry Agency (Rosleskhoz) has altered its position on certification several times, beginning with a vaguely worded requirement for some form of certification in the 1997 Forest Code [44] (Article 71), then removing that requirement in the subsequent version of the Code, and most recently, following a Presidential Instruction (Poruchenie 1037, point 2(e)) from 1 December 2013) directing the Russian federal and regional governments to take measures to encourage voluntary certification "in accordance with national and international standards" [45]. According to Andrei Ptichnikov, director of the FSC Russia office, the 1997 certification requirement was a response to efforts to promote certification by the World Wildlife Fund (WWF) and other environmental groups (Ptichnikov 2014).

This instability of policy positions and the direction of change suggests that FSC has affected forest policy. At a rhetorical level, numerous changes to policy language have taken place. Terms such as "forest certification" most obviously, but also "biodiversity," "sustainability," and "indigenous peoples," which are codified in FSC principles, only began to appear in Russian forestry legislation in the 1990s coinciding with the introduction of FSC, and appear with increasing frequency since then. At the center of Russian forest governance, the 2006 Forest Code lists among the legislation's primary objectives: "the sustainable management of forests and preservation of biological diversity, the preservation of their environmental functions such as water conservation and as a habitat for many species, the rational and non-depleting use, the participation of citizens and civil society in decision making, and the 'ensured conservation and protection of forests'" [46] (p. 20). Although there was little effort to enact these 
principles in practice, the language marks a shift from past laws that focused on extensive industrial forest management. In a protocol document summarizing June 2007 discussions between European Commission and Russian government officials in the EU-Russian Dialogue, a Russian government delegation member was quoted as stating that Russia is increasing its volume of certified forest territories despite relatively weak domestic demand, and that Russian environmental organizations such as WWF are closely "involved in the development of forest legislation" [47]. In 2008, the Ministry of Industry and Commerce and the Ministry of Agriculture issued a joint decree announcing a strategy for forest sector development to 2020 [48]. The strategy expressed dismay at the decline in Russia's exports and recommended greater learning from international practices, and preservation of the "ecological resource potential of the forests, their biological diversity, the role of forests in the stabilization of the global and regional state of the natural environment" [48]. The document then provides recommendations for improving forest policy, including a section on "developing forest certification" (in Section 6.3.2).

Another response to FSC certification is the creation of a rival national certification scheme, developed in cooperation with forest industry actors. Critics charge that alternative certification schemes often have lower sustainability and community engagement standards [19,49], [50] (pp. 55-58). Nevertheless, the development of a rival certification process signifies the state's recognition that some form of certification is necessary to gain market access globally. In Russia, in 2006, two national forest certification initiatives, one sponsored by the Ministry of Natural Resources and the World Bank, and the other by National Council of Voluntary Forest Certification in Russia, representing a group of timber exporters, combined their efforts to become members of the PEFC global certification process. This Russian National Certification Scheme has been vastly less successful than FSC certification, however [51] (p. 180). In Russia, between 2010 and April 2016, PEFC had granted only 16 chain of custody certificates and 11 forest management certificates. By 2013, FSC had certified over 33 million hectares of Russian forest, while PEFC had certified only 644 thousand hectares [51] (p. 180). Still, the Russian government's investment in an alternative certification program is a clear reaction to FSC.

\subsection{Enforcement Practices}

Beyond legislation and language, there have been shifts in how Russian laws are interpreted and enforced. In the Russian case, persistent differences between state forestry regulation and FSC standards have led to conflicts. Most notably, Russia's forestry law requires "full utilization" of the forested territory by private leaseholders who may be fined if they do not meet timber cutting requirements [52] (p. 281). Meanwhile, excessive cutting contradicts FSC standards. Malets states: "Forest certification standards ... support minimizing the impact of forest management, particularly logging, on forests and require the protection of key biotopes, ecologically important structural elements on logging sites and environmentally valuable forests, all of which contradict the 'full utilization' paradigm" [53] (p. 16). As a result, Russian forest leaseholders attempting to certify under FSC often find it difficult to comply with their lease agreement [52]. In a 2005 report aimed at providing practical guidance for FSC leaseholders on compliance with the FSC HCVF standard, WWF Russia explained that "unfortunately, at the present time a significant problem is created by contradictions between the demands of FSC certification regarding HCVF and Russian forest legislation" [54].

Yet some forestry practitioners observe that regional state regulators now operate with a more flexible understanding of the full utilization principle. FSC certification auditor Pavel Trushevskii states:

If earlier they fined foresters for insufficient cutting, now they relate more normally to this and understand that if a company doesn't need the birch, if there is no market for birch, or if in Eastern Siberia the birch is of poor quality, then why cut it down and burn it? Let the birch be left on the land and it will be better for nature. Forestry officials are beginning to compromise with the companies that we are certifying (Trushevskii 2014). 
Regions in the Northwest of Russia have been more likely than others to seek accommodation with FSC rules [55] (pp. 348-349). Tysiachniouk describes formal agreements, including a tripartite agreement between a forest company, the regulator Rosleskhoz, and the Karelian government in 2008 , allowing certification to proceed despite contradictions with Russian law by obtaining "special permission for measures that allow forest management intensification" [52] (p. 278). In Arkhangelsk, officials from the regional Ministry of Natural Resources and Forestry, industry representatives, and environmentalists have participated in annual meetings and occasional roundtables of the Arkhangelsk Forest Forum to resolve questions related to FSC certification. Andrei Shchegolov of the Arkhangelsk branch of WWF stated in 2008: "Earlier there were serious contradictions between the requirements of the international forest certification and the Russian forest legislation. ... Now they are eliminated: new rules on harvesting timber allow for the preservation of biodiversity" [56].

\section{Analysis: Conditions and Mechanisms that Facilitate FSC Influence on the Russian State}

The facilitating conditions that shape whether a certification scheme like FSC influences state policy include ineffective and decentralized forest governance, contradictions between state and FSC rules, and foreign market demand. These conditions activate mechanisms of influence such as professional and material incentives for state officials and bottom-up pressure on the state from firms and civil society groups. Below we see these factors play out in the Russian case, before examining their significant, but somewhat lesser, influence on Brazil's forest governance.

\subsection{Poor Quality and Decentralized Governance}

A history of ineffective state governance-and the industry's resulting poor reputation among global consumers-creates incentives for private actors to engage certification to compensate for lax domestic regulation [30] (pp. 80-81), [31] (p. 590). Private actors' engagement with certification then creates pressures for improved state regulation. Russia faces significant challenges in effectively governing its forest territory, in part due to the vast size and remoteness of Siberian and Far Eastern forests. Illegal logging has been a serious problem since the 1990s. The World Bank and WWF estimate that 20 percent of all logging in Russia violates the law [37] (p. xii). Ulybina reports from her study that key Russian forestry stakeholders consider the government to be "incompetent" and "historically 'self-isolated' and ignorant of forestry developments in other countries" [57] (pp. 148-149).

When existing governance models are ineffective, state actors, motivated by concern for their professional reputation, may seek to improve regulatory effectiveness. If private governance is seen as legitimate, domestically or globally, adherence to its rules can raise the credibility of state agencies [7] (p. 86), [17] (p. 70). State officials may engage directly with private certification representatives for information sharing and learning. FSC Russia has worked to shape forestry officials' understanding of sustainable forest management. For example, in 2006, Rosleskhoz and FSC collaborated in developing a plan to fight illegal logging. In response, the head of Rosleskhoz praised voluntary certification as a means to reduce illegal timber harvesting: "In the fight for transparency and ecological responsibility on the forest products market it is necessary to consolidate the efforts of all interested structures. Therefore, we only welcome the strengthening of cooperation between Rosleskhoz, FSC and the Russian national council on forest certification" [58]. Several working groups on certification, including the Public Forest Council convened in 2011 by Rosleskhoz, consider how to make domestic and FSC standards more compatible [52] (pp. 135-136). The council produced a document entitled "The Foundations of the State Policy for the Use, Protection and Reproduction of Forests in the Russian Federation for the Period to 2030" that was signed by the Prime Minister in September 2013 [53] (p. 15).

Russian state forest governance has been decentralized over time, increasing the number of actors involved in forest management venues where standards are interpreted and enforced. Decentralization multiplies opportunities for the FSC to influence state practices, both through professional norms and revenue concerns, and expands pressure points for market and civil society actors. The 2006 Russian Forest Code decentralized governance, requiring regional forest services to oversee leases to 
private actors and Russia's 83 regional governments to implement federal laws [35] (p. 201), [52,53,59]. The Forest Code also requires industry actors to take on roles, such as reforestation and firefighting, formerly carried out by the state. Regional authorities and industry actors alike have struggled to manage their new responsibilities [53] (p. 12), leading to creative compromise. Noting a shift from earlier state-FSC conflicts, Vladimir Chuprov of Greenpeace Russia states: “in 2005-2007, the situation significantly altered, and federal legislation delegated questions of forest management to the regional level, with a great deal of freedom. This in many ways resolved the situation, because the state system for managing forests was demonopolized-competition began and companies appeared that could formulate forest policy, and not just the state" (Chuprov 2014).

State officials have varied interests, depending on whether they are responsible for budgets or environmental protection-and consequently different responses to forest certification. Russian NGOs promoting certification argue that Rosleskhoz has been more open to FSC standards than the Ministry of Natural Resources, the Ministry for Economic Development and Trade, or the presidential executive [57] (p. 252). Lower-level actors in forest governance appear to be more supportive of certification, possibly because FSC standards fill gaps in implementation. Anatolii Kuritsyn of the certification training company LesEkspert gave a vivid example:

In most regions the very forest officials_-representatives of Rosleskhoz ... - they are in favor of certification, because it establishes order in the forest. If a forest user throws an empty oil drum in the forest, they will punish him for it and ... if, in addition to forest officials, someone else will also punish him, the [Rosleskhoz] auditor is only in favor of that (Kuritsyn 2014).

\subsection{Contradictions among Overlapping Standards}

The introduction of FSC rules creates contradictions among overlapping forestry standards. Lister's case studies in wealthy democracies reveal that "the contest between overlapping established public laws and new private forest rules [encourages] ongoing adaptive improvements in forest management policy and practices" [17] (p. 2). Malets agrees that this dynamic occurs in the Russian case, arguing that it is "plausible that creative and skilled certification supporters use the dormant opportunities that domestic institutions offer to push certification and promote changes on the ground. Tensions may open new opportunities for negotiating new practices and introducing them into forest management systems" [53] (p. 2).

This competition among standards can prompt a shift in state regulation or enforcement practices to accommodate FSC standards. Chuprov of Greenpeace describes Russian federal officials' attitudes towards FSC in the late 1990s and early 2000s as hostile, "because FSC practically stood as a competitor of the state in the forest; many approaches were in contradiction, and there were open conflicts" (Chuprov 2014). Trushevskii states: "the difficulty is the lack of agreement between international standards and demands of national legislation in the area of forest usage.... Therefore, they must find a compromise with the demands of foresters, who might be backwards in terms of international best practices of forest management" (Trushevskii 2014). These conflicts can force a dialogue among state and private actors, with FSC representatives contributing to the discussion directly or indirectly [55]. In some circumstances, these conflicts may result in greater awareness of FSC standards and informal or formal compromise.

\subsection{Foreign Market Demand}

FSC certificates are spread unevenly across Russia's 83 regions. Regional variation is strongly related to the export potential of forest products, which triggers industry pressure on regional governments to facilitate certification. Russia's Northwestern regions, such as Karelia and Komi, are oriented toward the European market, while firms in the Far East are more likely to export to China. In 2015, thirty-one regions in Russia contained FSC-certified territory [60]. In 2012, 43 chain of custody and 33 forest management certificates had been issued by FSC in the Northwest 
regions of Karelia, Arkhangelsk and Komi. In the much larger Far Eastern regions of Khabarovsk and Primorye, there were only eight chain of custody and nine forest management certificates [61]. Private actors in regions proximate to FSC-sensitive European markets not only have been more likely to certify, but also more likely to ask state actors to address contradictions between domestic regulation and FSC standards [53,62] (Trushevskii 2014). Similarly, regional governments overseeing greater numbers of certified companies appear more responsive to certification. The Republic of Karelia incorporated certification into its official Forest Plan, proposing that firms "accelerate the implementation of forest certification system in order to produce competitive products" and strive to "increase the volume of certified forest management in the country to $80 \%$ by 2018 ," over the current levels around 40 percent [63]. The Komi Republic's government program for the "Development of Forestry" does not mention certification specifically, but closely echoes FSC language as it announces that "the purpose of the program is to increase the profitability of forests while maintaining their environmental, social and economic values" [64].

In contrast, the forestry and environmental protection agencies of Khabarovsk and Primorye in the Far East do not offer any publicly available information about certification on their websites or in accessible documents. In Khabarovsk, a coalition of actors emerged in 2011 to object to the FSC national standards for Russia, particularly the need to identify "high conservation value forests" within forest management plans [62]. Regional governments and some industry actors argued that preserving HCVFs violated leaseholders' commitment to full utilization. These critics also claimed that "the existing (FSC) standards in the country today have been developed abroad and to a large extent do not take into account the Russian realities" [65]. The conflict was exacerbated by lack of foreign market demand-FSC certification is not preferred in the Chinese market, which accounts for more than 70 percent of Khabarovsk's regional timber exports [66]. These conflicts were eventually addressed in meetings among forest industry representatives, state officials, and NGOs, yet levels of certification in the Far East remain low. In other areas of Russia, where timber quality is poor, such as the Urals and Caucasus, there is also no market pressure to adopt certification, and companies instead sell to domestic and Central Asian markets (Trushevskii 2014).

As described above, Russia's state forest regulators at first rejected the idea of private certification. According to Ptichnikov of FSC Russia, state forestry officials "did not understand for a long time; they thought it was a violation of the law, [and] it decreases tax revenues" (Ptichnikov 2014). Some state officials saw FSC as externally imposed standards that would harm Russia's domestic forest industry [51] (p. 182). However, over time Russian state actors have come to accept certification, in part due to firm pressure. Ulybina argues that in Russia, "National forest policy has been affected by lobbying from big business, e.g., rules of forest lease distribution and environmental regulations have been changed for big investment projects" [57] (p. 251). Tatiana Yanitskaia of FSC Russia suggests that material interests drive the response of state actors, noting, "In many countries they think that if I certify my forest, I will improve reputation, image, or if I get certified I get better practices in the forest. It's still an idea which is not considered important by the (Russian) government. It will be in future, but not now" (Yanitskaia 2014).

\subsection{An Ambiguous Role: Civil Society Advocacy}

WWF and other NGOs introduced FSC certification to Russia. In the regions where NGOs are most active they provide pathways for regional governments to harmonize FSC standards with Russian laws. In the early 2000s WWF and a few regional governments jointly created several model forests, including the Pskov Model Forest and the Preluzie Model Forest in the Komi Republic, to demonstrate sustainable forest management and educate state foresters about global forestry standards [67], [52] (pp. 188-200). The model forest initiative included seminars, workshops, and trips to Sweden to see intensive logging operations. In the case of the Preluzie Model Forest, Tysiachniouk states that government officials saw "potential for bettering the region's economy" [40] (p. 280) and also benefited from WWF's small grants program that allowed state foresters to carry out research projects [40] (p. 284). 
WWF Russia and other NGOs continue to promote FSC, even as space for Russian civil society contracts. For example, the Karelia Regional Nature Conservancy (SPOK), an NGO, facilitated an agreement allowing certification to proceed in Karelia. Ulybina found that "(i)n the Komi Republic, the influence of a local NGO (Silver Taiga) has been so significant as to change the regional legislation and encourage the republican authorities to finance the stock-taking of virgin forests" [57] (pp. 249-250). However, since that time, both SPOK and Silver Taiga have been declared "foreign agents" for receiving funding support from Western donors. Both groups, as well as other NGOs, face serious obstacles to continuing their work given more stringent laws on civil society in Russia. In a 2015 editorial in the newspaper Vedomosti, the WWF Russia director of environmental policy and his colleague urged Russian companies and government officials: "instead of looking for enemies and complaints, it is necessary to adapt to objective environmental challenges and more effectively prepare to work in a market that requires compliance with international environmental standards, and to drive the domestic legal framework toward the requirements of the appropriate environmental certifications" [68].

\section{Comparison with Brazil}

Comparing Russia and Brazil alerts us to the importance of the timing of FSC's introduction into a country. International market pressures are a clear mechanism of influence in both cases. Certified forest companies in Brazil and Russia appear to have adopted FSC to achieve increased export market access, and in tandem pressured the state to adapt regulations to facilitate FSC certification. However, in Russia, FSC appeared as a mechanism for changing forest policy at a time when there were no competing sustainable forestry standards and few influential voices clamoring for better social and environmental practices in forestry. As a result, FSC's role in Russia in providing information on sustainability to state forestry officials was substantial, appealing to their desire for greater professionalization and increased revenues. In Brazil, forestry officials had already been exposed to transnational advocacy campaigns to protect biodiversity in the Amazon rainforest significantly prior to the introduction of the FSC.

\subsection{Revisions to State Policy}

Brazil's state forest governance has been a target of global criticism since the 1980s due to deforestation in the Amazon [69] (de Andrade 2016). Even before the introduction of FSC, Brazil responded to this global pressure in a variety of ways. For example, the Brazilian government created the Ministry of the Environment in 1992 to coincide with Rio Earth Summit where actors articulated principles, such as the interdependence of ecological, social, and economic factors, that were then included in the FSC framework [25] (p. 170). The Brazilian Forest Service (SFB), established in 2006, now places sustainable forestry at the center of its policy making [70]. Thus, Brazil's engagement with FSC has been one element in a longer process of transnational environmental influence, while FSC intervention in Russia was more novel and disruptive.

Nevertheless, we see a number of changes to Brazilian forest governance that coincide with FSC principles and standards. In 2004, the National Forestry Program and Conaflor, a newly created forestry commission, brought together public and private stakeholders to develop the 2006 Law on Public Forest Management [71] (pp. 134-135). This law, revised in 2012, set out rules on forest "concessions" (temporary management leases of Amazonian native forest) [39] (p. 39), and strengthened requirements that all concessions develop a "sustainable forest management plan" [72,73]. In recent years, the law was altered to require "independent certification schemes, such as FSC or similar as part of the concession requirements" [74] (p. 5). To the consternation of some critics, the plans provide a way for the Brazilian government to delegate oversight of Amazon territories to FSC (Werneburg 2016).

Brazil has taken other measures to better manage forests [39] (pp. xi-xii), such as combatting illegal logging by requiring a Document of Forest Origin to trace timber domestically [75] (p. 139). Moreover, in response to FSC standards, industry actors, working with the national standards agency (INMETRO), developed alternative management standards for tree plantations, "systems ... distinguished from 
FSC in the flexibility of their standards and the weight of industry representation" [76] (p. 85). Still, Brazilian Forest Service officials reportedly resist communicating directly with FSC certification bodies [39] (p. 40). According to an FSC-Brazil member organization, the government does not understand well what FSC does or how it works (De Andrade 2016).

In Brazil, there is less evidence of conflict between state regulations and FSC standards, although when the FSC was first introduced in the 1990s, "initial initiatives were hindered by doubts and conflicts among the logging industry representatives and proponents of this new scheme regarding how best to run such an initiative in the country" [39] (p. 35). Similar to Russia's competing national certification scheme, the Brazilian Forest Certification Programme (Programa Brasileiro de Certificação Floresta-known as CERFLOR) was created in partnership with PEFC and has been less successful than FSC [77] (p. 36). Yet some have found FSC certification useful in addressing the "deep-rooted culture of non-compliance" with forestry laws and that "forest certification is a mechanism that effectively influences the fulfillment of the country's legislation" [78]. Civil society groups associated with FSC have had some success in promoting more sustainable local government procurement policies, although the influence of FSC per se in this is unclear. In 2005, a campaign by Greenpeace Brazil (a member of FSC Brazil) led the largest city of Sao Paulo to adopt procurement commitments to "exclusively use timber of legal origin" [79], [30] (p. 74), yet problems with public procurement of illegal timber remain [39] (p. 40).

\subsection{Poor and Decentralized Governance}

Brazil has suffered from poor forest governance and unclear land tenure, notably in the Amazon [76] (pp. 63-64), [75] (pp. 136-138). Forest management plans were not required in Brazil until 1995; forest regulations are detailed and prescriptive [71], [75] (p. 137). One report concludes: "Powerful and diverse actors at various levels of government and society have made forest policy definition a playing field that is loaded with conflicts and prone to corruption and illegality" [39] (p. xii). Many of Brazil's forest initiatives are designed to address Amazon deforestation, a focus of transnational activism, such as the 2003 Action Plan for the Prevention and Control of Deforestation in the Legal Amazon (PPCDAm). Appeals to the professionalism of Brazilian forest regulators began before the FSC became active, but FSC still plays a role. Requiring sustainable forest management via FSC certification in Amazon forest concessions helps the government to monitor compliance with regulations in this enormous territory (Werneburg 2016). At the same time, FSC standards may be perceived as a threat to state actors' interests, especially when officials are complicit in illegal behavior. Espach notes that while Brazil's federal-level Environment Ministry officially supports certification, it "suffers from internal division and corruption" and may view FSC audits as "infringements on their authority" [76] (p. 85).

Decentralization has prompted regional variation in forest governance in Brazil. The 1988 Brazilian constitution devolved authority to lower levels of government, including primary powers in the national forest code [35] (p. 225). The 2006 forestry reform also delegated a number of forest management tasks to Brazilian states, including crafting forest management plans and managing concessions. Decentralization created opportunities to pursue new models in forest governance. Espach notes that "as of 2006, three state governments in the Amazon region (Amapa, Amazonas, and Para) sponsor incentive programs that support community-based forest certification through FSC by offering technical and financial assistance" [76] (p. 86). However, other regions did little to promote certification, or to manage forests effectively. While states could develop agreements with IBAMA to share forest governance responsibilities, "in many states, the limited personnel also lacked political motivation, technical skills, training, vehicles, and/or an operating budget to implement the agreements" [71] (p. 136). 


\subsection{Foreign Market Demand}

In Brazil, there is considerable regional variation in the extent of FSC adoption depending on the type of forest involved. The preponderance of certified forests is in plantations of eucalyptus and pine (about 30\% FSC) that produce timber for export, rather than the native tropical forest. Planted forests, which account for only 7 million hectares out of Brazil's 463 millions hectares of forests, produce about 90 percent of all industrial logs [80]. With the major destinations of Brazil's timber exports being the more environmentally concerned markets of the United States, Japan, and Europe [81], wood harvested from Amazonian native forests has a smaller export market due to international condemnation of Amazon deforestation and the lack of a clear chain of custody [82] (p. 26).

\subsection{Timing of Civil Society Mobilization}

In Brazil, NGOs such as WWF and the Rainforest Alliance have been influential in promoting FSC certification, but, unlike Russian NGOs, many organizations have a history of activism that predates the entry of FSC by decades. Romero and co-authors state: "Non-governmental entities responsible for independent certification have been operating in Brazil since the 1970s" [39] (p. 35). Espach argues: "The success of Brazil's FSC chapter is largely due to the network of local individuals, firms, NGOs, and certification agencies that predated the FSC but found in the program a workable tool for the pursuit of their shared interests" [30] (pp. 75-76, 80-81). According to Werneburg of FSC Brazil, the organization has had more success engaging business actors, particularly from plantations where certification levels are high, and NGOs interested in labor conditions rather than environmental NGOs or those based in the Amazon, demonstrating that the nature of civil society pressure will vary across states (Werneburg 2016; de Andrade 2016).

\section{Counterfactual: Is the FSC Necessary?}

Is it possible that these mechanisms influencing state policy could have been triggered in the absence of the FSC? A counterfactual approach $[83,84]$ asks whether significant progress toward sustainable forestry would have occurred in Russia and Brazil without FSC certification. State actors' receptivity to a domestic environmental movement, or significant market demand for sustainable products, could have led to the observed changes in Russia and Brazil, although likely to a lesser degree absent the FSC standards and third-party audits for firms. While these factors existed to some extent in Brazil without FSC, they did not exist in Russia, where the gap between global standards and domestic policy was greater.

First, the poor governance conditions we describe could potentially activate the professionalization mechanism alone, prompting forestry officials to seek guidance on regulatory standards and enforcement through professional networks other than FSC. However, there are not many active learning networks around sustainable forestry available to Russian or Brazilian forestry officials. Second, FSC has coordinated domestic networks among civil society activists and scientists to provide technical expertise in both Russia and Brazil that otherwise would not easily have come into existence.

Next, strong consumer demand for sustainable products could trigger more socially and environmentally sustainable policies. However, FSC itself has played a significant role in cultivating international demand for these products, enabling firms to convert it into economic advantage. In Russia, FSC was clearly key to pressure for sustainability, as firms only began to lobby the state when they perceived the need for market access or an economic benefit from certification. In Brazil, international market pressure preceded the entry of FSC through transnational civil society mobilization to stop deforestation in the Amazon rainforest.

Finally, could NGOs have achieved changes in state policy toward sustainability without FSC? Given the overall weakness of Russia's civil society and government repression of NGOs, it is implausible that environmental NGOs could have induced changes in Russian policy or 
implementation of sustainable forest practices without the economic incentives provided by FSC. In Brazil, FSC was less crucial because it intervened after a transnational advocacy campaign had successfully boycotted Amazon rainforest timber in European and North American markets. Still, even in Brazil, FSC has articulated a set of principles that is much more comprehensive than the boycott campaign and established accountability and verification processes. Thus, in both cases, FSC certification has influenced state policy, but with a greater effect in the more brittle Russian system.

\section{Conclusions}

Our analysis provides substantial evidence that FSC, a private certification scheme that directly targets firms and works around the state by shaping market demand, can influence a state's rhetoric, domestic policy, and patterns of engagement with industry actors. The cases of Russia and Brazil suggest a more general logic of how private certification schemes can shape state behavior over time, given certain background conditions. These findings are likely generalizable to states that share these interacting background factors-poor and decentralized domestic governance, overlapping public and private rules, and foreign market incentives. Given these conditions, industry and civil society actors pressure state officials to respond to certification standards, while regulators' desire for professionalization and increased revenue reinforces their demands. We expect that other private certification schemes may activate the same mechanisms, given the presence of the necessary background conditions. These could include the Marine Stewardship Council, PEFC, the Kimberley Process Certification Scheme, anti-child labor initiatives, and other fair trade, ethically produced, or environmentally sustainable product certifications.

Paradoxically, the FSC appears to have had a greater impact in Russia-the state that is less democratic and has a weaker environmental movement, but has a greater regulatory gap between global and domestic standards - than in Brazil. In Russia, FSC disrupted business as usual in the forest sector. The influence of FSC standards on Russian forest governance is notable in recent years; the state has wavered between resistance through rival national certification programs and accommodation of FSC principles. The need to meet FSC standards has been more disruptive and conflictual in Russia, leading to greater change than in Brazil. At the same time, the influence of FSC has varied regionally in both Russia and Brazil, depending on external market pressures and industry lobbying. Yet due to global attention on the issue of deforestation in the Amazon, the Brazilian state became attuned to sustainability principles even prior to the development of FSC standards and FSC may have had less independent impact on forest regulation in Brazil.

There are limits to the potential for FSC to influence state behavior in these two countries. Excessively poor governance may ultimately undermine FSC impact; as others have argued, effective governance requires a minimally effective state [57] (p. 252), [17] (p. 202). A state's regime type and sovereignty concerns also shape FSC influence. Multistakeholder global governance frameworks rest on the idea that state and nonstate actors can legitimately share regulatory authority to achieve better policy outcomes. However, in cases where state actors see decision-making authority as a zero-sum game, they may jealously guard their authority, even if this means losing the benefits that certification could provide. Repressive state laws also may limit the ability of NGOs to advocate for policy change in the direction of global standards. An additional constraint on the future of FSC in Russia and Brazil is the weak domestic market for FSC-certified products. Paradoxically, FSC has had the greatest impact in Brazil's planted forests rather than Amazonian native forest, due to the lack of a credible export market for Amazon timber. In Russia, the lack of a domestic market for certified timber is compounded by the fact that Chinese buyers also rarely demand certification, although this is changing as Chinese processors integrate into Western supply chains [51].

Despite these limits to the effectiveness of the FSC in Brazil and Russia, FSC certification has exhibited impacts on state policies on forest sustainability that are surprising under conditions of poor governance. These cases indicate that the FSC may exert influence on states, in complex ways that go beyond the intentions of the private governance scheme's creators. 
Acknowledgments: This research was supported by grants from the Social Sciences and Humanities Research Council of Canada (Insight Development Grant 430-2013-000379) and the University of British Columbia. The authors wish to thank Deborah Barros Leal Farias, Fabio Resmini, Erik Coates, and Hanna Dandanell for their impeccable research assistance, as well as Judith Kelley, Beth Simmons, Angela Fisher, Alicia Harley, Anh Le, Nancy Green Saraisky, and other participants in the May 2016 Workshop on Assessment Power in World Politics at the Harvard University Weatherhead Center, for their valuable comments on an early draft of this paper.

Author Contributions: Lisa McIntosh Sundstrom. and Laura A. Henry jointly conceived of the comparative project and carried out the interview research, analyzed the data, and wrote the paper.

Conflicts of Interest: The authors declare no conflict of interest.

\section{Appendix Interviews}

All interviews were carried out by the authors in May-June 2014 in Moscow, Russia, with the exception of Werneberg and de Andrade, which were carried out in July-August 2016.

\begin{tabular}{ll}
\hline \multicolumn{1}{c}{ Interviewee } & \multicolumn{1}{c}{ Organization } \\
\hline $\begin{array}{l}\text { Chuprov, Vladimir } \\
\text { De Andrade, Amanda }\end{array}$ & Greenpeace Russia \\
Karpachevskii, Mikhail & Bioatlântica Institute (IBIO), Brazil \\
Russian National Office, Forest Stewardship Council/Biodiversity \\
Kokorin, Aleksei & WWFservation Center \\
Kuritsyn, Anatolii & Lesekspert, Russia \\
Ptichnikov, Andrei & Russian National Office, Forest Stewardship Council \\
Shvarts, Evgenii & WWF-Russia \\
Slivyak, Vladimir & Eco-Defense, Russia \\
Stetsenko, Andrei & Center for Ecological Innovation, Russia \\
Trushevskii, Pavel & Lesnaya Sertifikatsiya (Forest Certification LLC), Russia \\
Werneberg, Andrea & Brazilian National Office, Forest Stewardship Council \\
Yanitskaia, Tatiana & Russian National Office, Forest Stewardship Council \\
\hline
\end{tabular}

\section{References and Note}

1. Green, J.F. Rethinking Private Authority: Agents and Entrepreneurs in Global Environmental Governance; Princeton University Press: Princeton, NJ, USA, 2013; ISBN 9781400848669.

2. Cashore, B.; Van Kooten, G.C.; Vertinsky, I.; Auld, G.; Affolderbach, J. Private or self-regulation? A comparative study of forest certification choices in Canada, the United States and Germany. For. Policy Econ. 2005, 7, 53-69. [CrossRef]

3. Chen, J.; Innes, J.L.; Kozak, R.A. An exploratory assessment of the attitudes of Chinese wood products manufacturers towards forest certification. J. Environ. Manag. 2011, 92, 2984-2992. [CrossRef] [PubMed]

4. Araujo, M.; Kant, S.; Couto, L. Why Brazilian companies are certifying their forests? For. Policy Econ. 2009, 11, 579-585. [CrossRef]

5. Cashore, B.; Auld, G.; Newsom, D. Governing Through Markets: Forest Certification and the Emergence of Non-state Authority; Yale University Press: New Haven, CT, USA, 2004; ISBN 0300101090.

6. Marx, A.; Cuypers, D. Forest certification as a global environmental governance tool: What is the macro-effectiveness of the Forest Stewardship Council? Regul. Gov. 2010, 4, 408-434. [CrossRef]

7. Gulbrandsen, L.H. Dynamic governance interactions: Evolutionary effects of state responses to non-state certification programs. Regul. Gov. 2014, 8, 74-92. [CrossRef]

8. Cubbage, F.; Diaz, D.; Yapura, P.; Dube, F. Impacts of forest management certification in Argentina and Chile. For. Policy Econ. 2010, 12, 497-504. [CrossRef]

9. Moore, S.E.; Cubbage, F.; Eicheldinger, C. Impacts of Forest Stewardship Council (FSC) and Sustainable Forestry Initiative (SFI) Forest Certification in North America. J. For. 2012, 110, 79-88. [CrossRef]

10. Pattberg, P. The institutionalization of private governance: How business and nonprofit organizations agree on transnational rules. Governance 2005, 18, 589-610. [CrossRef] 
11. Boström, M.; Hallström, K.T. NGO power in global social and environmental standard-setting. Glob. Environ. Politics 2010, 10, 36-59. [CrossRef]

12. Rosenau, J.N. Change, Complexity, and Governance in Globalizing Space. In Debating Governance: Authority, Steering, and Democracy; Pierre, J., Ed.; OUP Oxford: London, UK, 2000; pp. 167-200, ISBN 9780191583315.

13. Wapner, P. Politics beyond the state: Environmental activism and world civic politics. World Politics 1995, 47, 311-340. [CrossRef]

14. Bernstein, S. When is non-state global governance really governance? Utah Law Rev. 2010, 2010, 91-115.

15. Bartley, T. Institutional emergence in an era of globalization: The rise of transnational private regulation of labor and environmental conditions. Am. J. Sociol. 2007, 113, 297-351. [CrossRef]

16. Bernstein, S.; Cashore, B. Complex global governance and domestic policies: Four pathways of influence. Int. Aff. 2012, 88, 585-604. [CrossRef]

17. Lister, J. Corporate Social Responsibility and the State: International Approaches to Forest Co-Regulation; UBC Press: Vancouver, BC, Canada, 2011.

18. Cashore, B. Legitimacy and the privatization of environmental governance: How non-state market-driven (NSMD) governance systems gain rule-making authority. Governance 2002, 15, 503-529. [CrossRef]

19. Gulbrandsen, L.H. Overlapping public and private governance: Can forest certification fill the gaps in the global forest regime? Glob. Environ. Politics 2004, 4, 75-100. [CrossRef]

20. Giessen, L.; Burns, S.; Sahide, M.A.K.; Wibowo, A. From governance to government: The strengthened role of state bureaucracies in forest and agricultural certification. Policy Soc. 2016, 35, 71-89. [CrossRef]

21. Sahide, M.A.K. Towards state hegemony over agricultural certification: From voluntary private to mandatory state regimes on palm oil in Indonesia. J. Manag. Hutan Tanam. 2016, 22, 105-113. [CrossRef]

22. Chan, S.; Pattberg, P. Private rule-making and the politics of accountability: Analyzing global forest governance. Glob. Environ. Politics 2008, 8, 103-121. [CrossRef]

23. Goldstein, J.; Keohane, R.O. Ideas and Foreign Policy: An Analytical Framework. In Ideas and Foreign Policy: Beliefs, Institutions, and Political Change; Cornell University Press: Ithaca, NY, USA, 1993; pp. 3-30.

24. Thelen, K. How Institutions Evolve: Insights from Comparative Historical Analysis. In Comparative Historical Analysis in the Social Sciences; Mahoney, J., Rueschemeyer, D., Eds.; Cambridge University Press: New York, NY, USA, 2003; ISBN 0192140612.

25. Boström, M. How state-dependent is a non-state-driven rule-making project? The case of forest certification in Sweden. J. Environ. Policy Plan. 2003, 5, 165-180. [CrossRef]

26. Lemos, M.C.; Agrawal, A. Environmental governance. Annu. Rev. Environ. Resour. 2006, 297-325. [CrossRef]

27. Overdevest, C.; Zeitlin, J. Assembling an experimentalist regime: Transnational governance interactions in the forest sector. Regul. Gov. 2014, 8, 22-48. [CrossRef]

28. Prakash, A.; Potoski, M. Racing to the Bottom? Trade, Environmental Governance, and ISO 14001. Am. J. Political Sci. 2006, 50, 350-364. [CrossRef]

29. Vogel, D. Trading Up: Consumer and Environmental Regulation in a Global Economy; Harvard University Press: Cambridge, MA, USA, 1995; ISBN 9780674044685.

30. Espach, R. When is sustainable forestry sustainable? The Forest Stewardship Council in Argentina and Brazil. Glob. Environ. Politics 2006, 6, 55-84. [CrossRef]

31. Pattberg, P. Private governance and the South: Lessons from global forest politics. Third World Q. 2006, 27, 579-593. [CrossRef]

32. FSC International. Our Vision and Mission. Available online: https://ic.fsc.org:443/en/about-fsc/visionmission (accessed on 24 August 2016).

33. FSC International. The 10 Principles. Available online: https:/ /ic.fsc.org:443/en/certification/principlesand-criteria/the-10-principles (accessed on 24 August 2016).

34. Earth Policy Institute. Eco-Economy Indicators-Forest Cover-World Forest Area Still on the Decline (2012). Available online: http:/ / www.earth-policy.org/indicators/C56 (accessed on 8 December 2016).

35. McDermott, C.L.; Cashore, B.; Kanowski, P. Global Environmental Forest Policies: An International Comparison; Earthscan: London, UK, 2010.

36. Food and Agriculture Organization (FAO). Forests and the Forestry Sector: Brazil. Food and Agriculture Organization of the United Nations. Available online: http:/ / www.fao.org/forestry/country/57478/en/ bra/ (accessed on 8 August 2016). 
37. Food and Agriculture Organization (FAO). The Russian Federation Forest Sector Outlook Study to 2030. Food and Agriculture Organization of the United Nations. Available online: http:/ / www.fao.org/forestry / outlook/79738/en/ (accessed on 22 October 2016).

38. Cashore, B.; Gale, F.; Newsom, D.; Scott, D.; Branford, N.; Coppock, J. Confronting Sustainability: Forest Certification in Developing and Transitioning Countries; Report Num.; Yale F\&ES Publication Series: New Haven, CT, USA, 2006.

39. Romero, C.; Putz, F.E.; Guariguata, M.R.; Sills, E.O.; Maryudi, A.; Ruslandi. The Context of Natural Forest Management and FSC Certification in Brazil; Occasional Paper 148; Center for International Forestry Research (CIFOR): Bogor, Indonesia, 2015.

40. Tysiachniouk, M. Russia. In Confronting Sustainability: Forest Certification in Developing and Transitioning Countries; Cashore, B., Gale, F., Newsom, D., Scott, D., Branford, N., Coppock, J., Eds.; Yale School of Forestry \& Environmental Studies: New Haven, CT, USA, 2006; pp. 261-297.

41. FSC International. Private correspondence on file with the authors, 20 April 2016.

42. FSC International. Facts \& Figures March 2016. Available online: https://ic.fsc.org (accessed on 11 August 2016).

43. FSC Russia. Facts and Figures [Fakty i Tsifry]. Available online: https://ru.fsc.org/ru-ru/chto_my_delaem/ facts_and_figures (accessed on 8 December 2016).

44. State Duma of the Russian Federation. Russian Federation Forest Code; State Duma of the Russian Federation: Moscow, Russia, 1997.

45. President of the Russian Federation. List of Instructions on Conclusions of the State Council Presidium Session (Perechen' poruchenii po itogam zasedaniia prezidiuma Gosudarstvennogo soveta). 1 December 2013. Available online: http:/ / www.kremlin.ru/acts/assignments/orders/18091 (accessed on 29 September 2016).

46. Hitchcock, E. The 2006 Forest Code of the Russian Federation: An evaluation of environmental legislation in Russia 1. ASEES 2010, 24, 19-39.

47. Rosleskhoz. Protocol of the First Meeting of the Expert Subgroup on Regulation of the Forest Sector, Forest Usage and Forest Conservation of the EU-Russia Dialogue [Protokol Pervogo zasedaniia ekspertnoi podgruppy po provaoprimeneniiu v lesnom sektore, lesoupravleniiu I okhrane lesov Dialoga EC-Rossiia]. Available online: http:/ / www.rosleshoz.gov.ru/activity/inter/docs/3 (accessed on 13 July 2016).

48. Ministry of Industry and Commerce of the Russian Federation, Decree of MinPromTorg No 248, Minselkhoz No 482 'On Confirmation of the Strategy for Development of the Forest Complex of the Russian Federation until 2020' [Ob Utverzhdenii Strategii Razvitiia Lesnogo Kompleksa Rossiiskoi Federatsii Na Period Do 2020 Goda]. Available online: http:/ / base.consultant.ru/cons/cgi/online.cgi?req=doc;base=LAW;n=99108 (accessed on 18 July 2016).

49. Clark, M.R.; Kozar, J.S. Comparing sustainable forest management certifications standards: A meta-analysis. Ecol. Soc. 2011, 16, 3. [CrossRef]

50. Overdevest, C. Comparing forest certification schemes: The case of ratcheting standards in the forest sector. Socio Econ. Rev. 2009, 8, 47-76. [CrossRef]

51. Ulybina, O.; Fennell, S. Forest certification in Russia: Challenges of institutional development. Ecol. Econ. 2013, 95, 178-187. [CrossRef]

52. Tysiachniouk, M. Transnational Governance Through Private Authority: The Case of the Forest Stewardship Council Certification in Russia; Wageningen Academic Pub: Wageningen, The Netherlands, 2012.

53. Malets, O. When transnational standards hit the ground: Domestic regulations, compliance assessment and forest certification in Russia. J. Environ. Policy Plan. 2014, 1-28. [CrossRef]

54. WWF Russia. High Conservation Value Forests: A Practical Guide [Lesa Vysokoi Prirodookhrannoi Tsennosti: Prakticheskoe Rukovodstvo]; WWF Russia: Moscow, Russia, 2005.

55. Tulaeva, S. The adventures of global standards in Russia: The implementation of FSC certification in the Russian forestry sector through the concept of global legal pluralism. J. Leg. Plur. Unoff. Law 2013, 45, 340-356. [CrossRef]

56. Chistiakova, A. Participants in Arkhangelsk forestry forum learned how to harvest timber correctly [Uchastnikov Arkhangel'skogo lesnogo foruma nauchili pravil'no valit' les]. Ross. Gaz. 2013. Available online: https:/ /rg.ru/2013/04/08/reg-szfo/lesoruby-anons.html (accessed on 11 August 2016). 
57. Ulybina, O. Interaction, cooperation and governance in the Russian forest sector. J. Rural Stud. 2014, 34, 246-253. [CrossRef]

58. Grevtsov, A. FSC Promotion. Russia enters the troika of leading countries in area of certified forest [FSC-Prodvizhenie. Po ploshadi certifitsirovannykh lesov Rossiia voshla v troiku stran-liderov]. Rossiiskaia lesnaia gazeta 2006, 31-32, 161-162.

59. Malets, O. From Transnational Voluntary Standards to Local Practices: A Case Study of Forest Certification in Russia Olga Malets; MPIfG Discussion Paper 11/7; Max-Planck-Institut: Munich, Germany, 2011.

60. FSC Russia. Annual Report of FSC Russia and the NIS for 2015 [Godovoi Otchet FSC Rossii i SNG za 2015]. Available online: https:/ / ru.fsc.org/ (accessed on 8 December 2016).

61. FSC Russia. Annual Report of FSC Russia for 2012 [Godovoi Otchet FSC Russia, 2012]. Available online: https:/ /ru.fsc.org/ (accessed on 8 December 2016).

62. Henry, L.A.; Tysiachniouk, M. The uneven response to global environmental vovernance: Contentious politics around forest certification in Russia. Presented at the Annual Meeting of the Association for Slavic, East European, and Eurasian Studies, New Orleans, LA, USA, 15-18 November 2012.

63. Government of the Republic of Karelia. Forestry Plan for the Republic of Karelia [Lesnoi Plan Respubliki Karelia]. 2012. Available online: http://www.gov.karelia.ru/Legislation/docs/2014/08/258-r_1.html (accessed on 8 December 2016).

64. Komi Republic Ministry of Natural Resources and Environment. Komi Republic State Program `Development of Forest Management’ [Gosudarstvennaia Programma Respubliki Komi ‘Razvitie Lesnogo Khosiaistva']. Available online: http:/ / mpr.rkomi.ru/page/14474/ (accessed on 8 December 2016).

65. Doronina, N. Experts: Forestry standards do not correspond with Russian realities [Eksperty: Lesnye standarty ne sootvetsvuiut Rossiiskim realiam]. Ross. Gaz. 2011. Available online: https://rg.ru/2011/09/ 29/reg-dvostok/les.html (accessed on 11 August 2016).

66. Khabarovsk Krai Ministry of Natural Resources. Khabarovsk Krai Forest Production [Realizatsiia Lesoproduktsii Khabarovskogo Kraia]. Available online: https://mpr.khabkrai.ru/Deyatelnost/ Lesopolzovanie/223 (accessed on 8 December 2016).

67. Tysiachniouk, M.; Henry, L.A. Managed citizenship: Global forest governance and democracy in Russian communities. Int. J. Sust. Dev. World 2015, 22, 476-489. [CrossRef]

68. Shvartz, E.; Zgurovskii, K. Ecological standards and economic development [Ekologicheskie standarty i ekonomicheskoe razvitie]. Vedomosti 2015. Available online: http:/ / www.vedomosti.ru/opinion/articles / 2015/11/24/618018-zelenaya-revolyutsiya-standartnie-trebovaniya (accessed on 11 August 2016).

69. Kolk, A. Forests in International Environmental Politics: International Organisations, NGOs and the Brazilian Amazon; International Books: Utrecht, The Netherlands, 1996.

70. CIFOR. Brazil Forges Forward on Path to Sustainable Forest. Forest News, 2012. Available online: http: / / blog.cifor.org/8196/brazil-forges-forward-on-path-to-sustainable-forest-development?fnl=en (accessed on 11 August 2016).

71. Bauch, S.; Sills, E.; Rodriguez, L.; McGinley, K.; Cubbage, F. Forest policy reform in Brazil. J. For. 2009, 107, 132-138.

72. Government of Brazil. Law No 11.284 (LEI No 11.284) on Public Forest Management for Sustainable Production of 2 March 2006. Available online: http://www.mma.gov.br/port/conama/legiabre.cfm? codlegi=485 (accessed on 23 August 2016).

73. Government of Brazil. Law No 12.651 (LEI No 12.651) on the Protection of Native Vegetation of 25 May 2012. 2012. Available online: http://www.planalto.gov.br/ccivil_03/_ato2011-2014/2012/lei/L12651compilado. htm (accessed on 23 August 2016).

74. Azevedo-Ramos, C.; Silva, J.N.M.; Merry, F. The evolution of Brazilian forest concessions. Elem. Sci. Anth. 2015, 3, 48. [CrossRef]

75. McDermott, C.L.; Irland, L.C.; Pacheco, P. Forest certification and legality initiatives in the Brazilian Amazon: Lessons for effective and equitable forest governance. For. Policy Econ. 2015, 50, 134-142. [CrossRef]

76. Espach, R. Private Environmental Regimes in Developing Countries; Palgrave Macmillan: New York, NY, USA, 2009.

77. Carneiro, M.S.; Amaral Neto, M.; Ramos Castro, E.M. Sociedade, Florestas e Sustentabilidade; Instituto Internacional de Educação do Brasil \NAEA: Belém, Brazil, 2013. 
78. Basso, V.M.; Jacovine, L.A.G.; Alves, R.R.; Vieira, S.L.P. Influência da certificação florestal no cumprimento da legislação ambiental e trabalhista na região amazônica. Acta Amaz. 2011, 41, 69-76. [CrossRef]

79. Inter Press Service. BRAZIL: Saving the Amazon Depends on Consumers. 11 November. Available online: http:/ / www.ipsnews.net/2005/11/brazil-saving-the-amazon-depends-on-consumers / (accessed on 8 December 2016).

80. President's Office for Strategic Matters. Government of Brazil. Strategic Note \#4-Planted Forests: Bases for a National Policy [Nota Estratégica 4-Florestas Plantadas: Bases Para a Política Nacional—Julho de 2014]. Available online: http:/ /www.sae.gov.br/imprensa/noticia/destaque/nota-estrategica-4-florestasplantadas-bases-para-a-politica-nacional-\%e2\%80\%93-julho-de-2014/ (accessed on 21 April 2016).

81. European Timber Trade Federation. Gateway to International Trade: Country Profile Brazil. Available online: http:/ / www.timbertradeportal.com/countries/brazil/ (accessed on 9 August 2016).

82. Pinto, L.F.G.; McDermott, C.L. Equity and forest certification-A case study in Brazil. For. Policy Econ. 2013, 30, 23-29. [CrossRef]

83. Levy, J.S. Counterfactuals and case Studies. In The Oxford Handbook of Political Methodology (online); Box-Steffensmeier, J., Brady, H.E., Collier, D., Eds.; Oxford University Press: Oxford, UK, 2009; ISBN 9780191577307.

84. Weber, M. The Methodology of the Social Sciences; Shils, E.A., Finch, H.A., Eds.; Free Press: Glencoe, IL, USA, 1949.

(C) 2017 by the authors. Licensee MDPI, Basel, Switzerland. This article is an open access article distributed under the terms and conditions of the Creative Commons Attribution (CC BY) license (http://creativecommons.org/licenses/by/4.0/). 